\title{
IKLIM KOMUNIKASI RRI PALANGKA RAYA SEBAGAI \\ LEMBAGA PENYIARAN PUBLIK
}

\author{
Oleh \\ Aquarini \\ Program Studi IImu Komunikasi FISIP Universitas Muhammadiyah Palangkaraya
}

\section{ABSTRAK}

Penelitian ini untuk mendeskripsikan, menjelaskan dan menganalisis implementasi Peraturan Pemerintah Nomor 53 Tahun 2010 di lingkungan Pemerintah Kota Palangka Raya dan faktor apa yang mempengaruhi implementasi Peraturan Pemerintah Nomor 53 Tahun 2010 di lingkungan Pemerintah Kota Palangka Raya.

Sebuah iklim komunikasi dan organisasi merupakan hal yang perlu menjadi perhatian seorang pimpinanan organisasi karena faktor tersebut banyak sedikitnya ikut mempengaruhi tingkah laku karyawan. Komunikasi dalam konteks apapun adalah bentuk dasar adaptasi terhadap lingkungan. Untuk dapat menciptakan iklim komunikasi dan organisasi yang baik perlu memahami kedua hal tersebut serta keadaan karyawan khususnya di lingkungan kerja kantor Radio Republik Indonesia Palangka Raya sebagai Lembaga Penyiaran Publik.

Metode pendekatan yang digunakan dalam penelitian ini adalah pendekatan deskriftif kuantitatif dengan analisis persentase rata-rata untuk melihat gambaran iklim komunikasi di RRI Palangka Raya Sebagai Lembaga Penyiaran. Secara konseptual iklim komunikasi RRI Palangka Raya mempunyai ciri khas sebagai lembaga penyiaran publik terutama gambaran sikap karyawannya.

Adapun hasil analisis dan pembahasan tesis ini adalah Iklim komunikasi di RRI Palangka Raya dapat digambarkan sebagai suatu suasana yang bermakna bagi para karyawan dalam menjalankan tugasnya sebagai karyawan RRI setelah ada perubahan posisi sebagai lembaga penyiaran public (LPP). Ini menunjukkan bahwa setelah perubahan sebagai LPP, karyawan RRI Palangka Raya juga merasakan perubahan, tidak hanya melayani publik secara eksternal tapi juga secara internal antar karyawan. Sebagai karyawan RRI, mereka memiliki keterikatan sesuai dimensi iklim komunikasi organisasi untuk saling mendukung dalam pencapaian tujuan pelayanan public, keterlibatan dalam berbagai peran dan tugas RRI dalam menjalankan fungsi social media massa, di samping factor saling percaya, diiringi keyakinan dan kredibilitas hubungan serta keterbukaan dalam organisasi, yang memberi makna pada iklim komunikadi di RRI Palangka Raya.

\section{Kata Kunci : Iklim Organisasi, Lembaga Penyiaran}

\section{PENDAHULUAN}

Dunia penyiaran di Indonesia berkembang pesat seiring dengan kemajuan teknologi serta dinamika masyarakat. Untuk memberikan keseimbangan dalam memperoleh informasi, pendidikan, kebudayaan, dan hiburan yang sehat pada masyarakat, diperlukan lembaga penyiaran publik yang bersifat independen, netral, tidak komersial, yang tidak semata-mata memproduksi acara siaran sesuai tuntutan liberalisasi dan selera pasar, serta bukan pula sebagai corong pemerintah, melainkan berfungsi memberikan layanan untuk kepentingan masyarakat.

Lembaga penyiaran publik membuka ruang publik (public sphere) dengan memberikan hak memperoleh informasi yang benar (right to know) dan menyampaikan pendapat atau aspirasi (right to express) bagi masyarakat sehingga menempatkan masyarakat sebagai warga negara. Lembaga penyiaran publik diperlukan oleh Negara Kesatuan Republik Indonesia yang merupakan negara kepulauan, berfungsi sebagai identitas nasional (flag carrier), pemersatu bangsa dan pembentuk citra positif bangsa di dunia internasional, selain bertugas menyiarkan informasi, pendidikan, budaya, dan hiburan.

Radio Republik Indonesia Palangka Raya adalah lembaga penyiaran publik milik bangsa dengan disahkanya Undang-Undang Nomor 32 tahun 2002 tentang Penyiaran RRI saat itu berstatus lembaga penyiaran Publik. Sebagai lembaga penyiaran publik yang bersifat independen, netral, tidak komersil dan berfungsi melayani kebutuhan 
masyarakat RRI Palangka Raya terdiri dari atas Dewan Pengawas dan Dewan Direksi. Status sebagai lembaga penyiaran publik diatur di dalam Pasal 14 ayat (2) dan (3) Undang-Undang Nomor 32 tahun 2002 tentang Penyiaran, yang berbunyi sebagai berikut:

Pasal 14 ayat (2)

“Lembaga Penyiaran Publik sebagaimana dimaksud dalam ayat (1) terdiri atas Radio Republik Indonesia dan Televisi Republik Indonesia yang stasiun pusat penyiarannya berada di ibukota Negara Republik Indonesia".

Pasal 14 ayat (3)

Di daerah provinsi, kabupaten, atau kota dapat didirikan Lembaga Penyiaran Publik lokal.

Selain itu juga Status sebagai lembaga penyiaran publik ditugaskan melalui Peraturan Pemerintah Nomor 11 tahun 2002 yang merupakan pelaksanaan lebih lanjut Undang-Undang Nomor 32 tahun 2002 tersebut. Berdasarkan Pasal 7 ayat (1) Peraturan Pemerintah Nomor 11 tahun 2002 tentang Penyelenggaraan Penyiaran Lembaga Penyiaran Publik menyebutkan:

"RRI dan TVRI merupakan lembaga penyiaran yang telah berdiri dan ditetapkan sebagai Lembaga Penyiaran Publik sebagaimana dimaksud dalam UndangUndang Nomor 32 Tahun 2002 tentang Penyiaran".

Sebelum menjadi Lembaga Penyiaran Publik Radio Republik Indonesia berstatus sebagai Perusahaan Jawatan (Perjan) yaitu badan usaha milik negara (BUMN) yang tidak mencari untung. Dalam status perusahaan jawatan, RRI telah menjalankan prinsipprinsip radio publik yang independen. Perusahaan jawatan dapat dikatakan sebagai status transisi dari Lembaga Penyiaran Publik menuju Lembaga Penyiaran Publik pada masa reformasi. Perubahan RRI menjadi Lembaga Penyiaraan Publik telah melampaui proses yang cukup panjang seiring semangat demokratisasi media yang berjalan seiring momentum reformasi. Sebelumnya, Radio Republik Indonesia adalah lembaga penyiaran pemerintah yang merupakan unit kerja Departemen Penerangan. Fungsi RRI sebagai lembaga penyiaran publik tidak hanya memberikan informasi yang aktual, tepat dan terpercaya, namun juga memberikan nilai-nilai edukatif seperti memberikan porsi pada siaran pendidikan, baik secara instruksional seperti siaran SLTP, SMA dan Universitas terbuka, juga memberikan pendidikan masyarakat seperti siaran pedesaan, siaran wanita, siaran nelayan, dan lain-lain. Tidak ketingggalan RRI juga menyediakan siaran yang menyajikan nilai seni dan budaya bangsa yang dikemas dalam sajian yang menarik. Hiburan musik dari manca Negara pun tersaji apik dalam siaran RRI. Coverage siaran RRI tidak saja di dalam negeri namun juga menembus sampai manca negara yang tersaji dalam Voice of Indonesia (Siaran Luar Negeri RRI). Menurut Dedy Mulyana Budaya adalah komunikasi dan komunikasi adalah budaya, dengan kata lain tak mungkin memikirkan komunikasi tanpa memikirkan konteks dan makna kulturnya. (Mulyana, 2011)

Dalam proses pencapaian tujuan dalam organisasi yang kondusif, informasi memiliki aliran dalam proses penyebarannya, karena informasi tidak mengalir secara harfiah melainkan dikomunikasikan. Yang sesungguhnya terlihat adalah penyampaian suatu pesan, interpretasi penyampaian pesan tersebut, dan penciptaan penyampaian lainnya. Penciptaan, penyampaian dan interpretasi pesan merupakan proses yang mendistribusikan pesan-pesan keseluruh organisasi sesuai dengan hirarki yang dimilikinya.

Aliran informasi dalam struktur organisasi idealnya bersifat timbal balik, interaktif, dialogis dan partisipatoris pada seluruh tingkatan, yang berorientasi kepada pemakai dengan mendayagunakan teknologi yang menyatu pada setiap proses komunikasi. Komunikasi didudukkan sebagai proses dialog untuk berbagai informasi, sehingga informasi merupakan pertukaran informasi di antara partisipan yang terjadi dari waktu ke waktu dan bukan lagi hanya transfer informasi. Organisasi terdiri dari orang-orang dalam berbagai jabatan. Ketika orang-orang dalam jabatan berkomunikasi, maka berkembang keteraturan pertukaran informasi, siapa berbicara kepada siapa dan informasi apa yang dipertukarkan. Lokasi setiap individu dalam pola dan jaringan yang 
terjadi memberi fungsi, peranan dan kewenangan kepada orang tersebut dalam menyampaikan dan atau menerima informasi.

Selain itu pula sebuah iklim komunikasi dan organisasi merupakan hal yang perlu menjadi perhatian seorang pimpinanan organisasi karena faktor tersebut banyak sedikitnya ikut mempengaruhi tingkah laku karyawan. Komunikasi dalam konteks apapun adalah bentuk dasar adaptasi terhadap lingkungan (Mulyana, 2011). Untuk dapat menciptakan iklim komunikasi dan organisasi yang baik perlu memahami kedua hal tersebut serta keadaan karyawan khususnya di lingkungan kerja kantor Radio Republik Indonesia Palangka Raya.

Dengan memperhatikan permasalahan tersebut di atas, maka dalam penulisan tesis ini penulis mengangkat topik dengan judul "IKLIM KOMUNIKASI RRI PALANGKA RAYA SEBAGAI LEMBAGA PENYIARAN PUBLIK".

\section{LANDASAN TEORI}

Iklim komunikasi telah melahirkan beberapa definisi, di antaranya: Menurut Tagiuri, Iklim Komunikasi Organisasi adalah kualitas yang relatif abadi dari lingkungan internal organisasi yang dialami oleh anggotaanggotanya, mempengaruhi tingkah laku mereka serta dapat diuraikan dalam istilah nilai-nilai suatu set karakteristik tertentu dari lingkungan. (Soemirat, Ardianto, Suminar, 1999).

Hillreiger dan Slocum mengatakan Iklim Komunikasi adalah suatu set atribut organisasi, yang menyebabkan bagaimana berjalannya subsistem organisasi terhadap anggota dan lingkungannya. (Soemirat, Ardianto, Suminar,1999).

Redding mengatakan iklim komunikasi merupakan fungsi kegiatan yang terdapat dalam organisasi untuk menunjukkan kepada anggota organisasi bahwa organisasi tersebut mempercayai mereka dan memberi mereka kebebasan dalam mengambil resiko; mendorong mereka dan memberi mereka tanggung jawab dalam mengerjakan tugastugas mereka dan menyediakan informasi yang terbuka dan cukup tentang organisasi; mendengarkan dengan penuh perhatian serta memperoleh informasi yang dapat dipercayai dan terus terang dari anggota organisasi; secara aktif memberi penyuluhan kepada pra anggota organisasi sehingga mereka dapat melihat bahwa keterlibatan mereka penting bagi keputusan-keputusan dalam organisasi; dan menaruh perhatian pada pekerjaan yang bermutu tinggi dan memberi tantangan. (Pace dan Faules, 2002)

Pace and Faules mengatakan iklim komunikasi terdiri dari persepsi-persepsi atas unsur-unsur organisasi dan pengaruh unsurunsur tersebut terhadap komunikasi. (Pace dan Faules, 2002). Dennis mendefinisikan iklim komunikasi organisasi sebagai kualitas pengalaman yang bersifat objektif mengenai lingkungan internal organisasi, yang mencakup persepsi anggota organisasi terhadap pesan dan hubungan pesan dengan kejadian yang terjadi di dalam organisasi. (Soemirat, Ardianto,1999)

Untuk menunjukkan kepada anggota organisasi bahwa organisasi tersebut mempercayai mereka dan memberi mereka kebebasan dalam mengambil resiko; mendorong mereka dan memberi mereka tanggung jawab dalam mengerjakan tugastugas mereka dan menyediakan informasi yang terbuka dan cukup tentang organisasi; mendengarkan dengan penuh perhatian serta memperoleh informasi yang dapat dipercayai dan terus terang dari anggota organisasi; secara aktif memberi penyuluhan kepada pra anggota organisasi sehingga mereka dapat melihat bahwa keterlibatan mereka penting bagi keputusan-keputusan dalam organisasi; dan menaruh perhatian pada pekerjaan yang bermutu tinggi dan memberi tantangan. Iklim komunikasi di dalam sebuah organisasi itu penting karena secara tidak langsung iklim komunikasi organisasi dapat mempengaruhi cara hidup orang-orang di dalam sebuah organisasi: kepada siapa orang-orang berbicara, siapa saja yang disukai, bagaimana perasaan masing-masing orang, bagaimana kegiatan kerja berlangsung dan bagaimana perkembangan orang-orang di dalam 
organisasi (Pace dan Faules, 2002). Menurut Redding, yang dikutip oleh Pace dan Faules menyatakan bahwa "iklim komunikasi jauh lebih penting daripada keterampilan atau teknik-teknik komunikasi semata-mata dalam menciptakan suatu organisasi yang efektif". (Pace dan Faules, 2002)

Dari sini dapat dilihat bahwa iklim komunikasi di dalam sebuah organisasi itu perlu untuk diperhatikan agar dapat menciptakan sebuah organisasi yang efektif. Di dalam buku komunikasi organisasi yang ditulis oleh Pace dan Faules menegaskan hal ini dengan mengemukakan bahwa iklim komunikasi tertentu memberi pedoman bagi keputusan dan perilaku individu. Keputusankeputusan yang diambil oleh anggota organisasi untuk melaksanakan pekerjaan mereka secara efektif, untuk mengikatkan diri mereka dengan organisasi, untuk bersikap jujur dalam bekerja, untuk meraih kesempatan dalam organisasi secara bersemangat, untuk mendukung para rekan dan anggota organisasi lainnya, untuk melaksanakan tugas secara kreatif, dan untuk menawarkan gagasan-gagasan inovatif bagi penyempurnaan organisasi dan operasinya, semua ini dipengaruhi oleh iklim komunikasi. Iklim yang negatif dapat benar-benar merusak yang dibuat anggota organisasi mengenai bagaimana mereka akan bekerja dan berpartisipasi untuk organisasi. (Pace dan Faules,

Iklim komunikasi yang penuh rasa persaudaraan mendorong para anggota organisasi untuk berkomunikasi sercara terbuka, rileks, ramah dengan anggota yang lain. Sedangkan iklim komunikasi yang negatif menjadikan anggota tidak berani berkomunikasi secara terbuka dan penuh rasa persaudaraan.

(Arni,

2004)

Jadi, iklim komunikasi memainkan peranan sentral dalam mendorong anggota organisasi untuk mencurahkan usaha kepada pekerjaan mereka dalam organisasi. (Pace dan Faules, 2002). Dari sini dapat dikatakan bahwa iklim komunikasi organisasi memiliki pengaruh yang cukup penting bagi motivasi kerja dan masa kerja pegawai dalam organisasi. Iklim komunikasi yang positif cenderung meningkatkan dan mendukung komitmen pada organisasi dan iklim komunikasi yang kuat seringkali menghasilkan praktik-praktik pengelolaan dan pedoman organisasi yang lebih mendukung (Pace dan Faules, 2002). Hal ini didukung pula Soemirat, Ardianto dan Suminar bahwa iklim komunikasi organisasi yang positif tidak hanya menguntungkan organisasi namun juga penting bagi kehidupan manusia-manusia di dalam organisasi tersebut. (Ardianto dan Suminar, 1999)

Dari uraian di atas mengenai iklim komunikasi organisasi, kita dapat melihat pentingnya peran iklim komunikasi organisasi bagi kehidupan sebuah organisasi. Oleh karena itu iklim komunikasi organisasi merupakan hal penting yang tidak boleh diabaikan, tetapi harus diperhatikan oleh organisasi.

\section{METODE PENELITIAN}

Metode pendekatan yang digunakan dalam penelitian ini adalah pendekatan deskriftif kuantitatif dengan analisis persentase rata-rata untuk melihat gambaran iklim komunikasi di RRI Palangka Raya Sebagai Lembaga Penyiaran. Secara konseptual iklim komunikasi RRI Palangka Raya mempunyai ciri khas sebagai lembaga penyiaran publik terutama gambaran sikap karyawannya. Pendekatan ini relevan dengan topik penelitian yang akan membahas gambaran iklim komunikasi di sebuah media massa yakni radio setelah reposisi sebagai lembaga penyiaran publik.

Artinya topik yang dijadikan gambaran pokok kajian sesuai dengan tatanan, sistem nilai, norma, perilaku dan aspek sosiologis lainnya serta khalayak dalam kehidupan kesehariannya.

Penelitian ini menggunakan metode penelitian dengan analisis persentase rata-rata hanya dengan menggunakan satu variable yakni variable yakni iklim komunikasi di RRI 
Palangka Raya dengan lima dimensi. Setiap dimensi ada indicator yang merujuk ke teori.

Seluruh temuan yang akan dianalisis disajikan dalam bentuk tabulasi tunggal dengan skala pengukuran Likert. Setiap tabel akan diinterpretasi dengan merujuk pada teori dan data yang ada.

Analisis data yang digunakan dalam penelitian ini adalah analisis regresi linier sederhana. Sebelum dilakukan lebih dahulu analisis persentase rata-rata untuk mendeskripsikan setiap variabel dengan rumus sebagai berikut: (Walizer :1993)

$$
P=f / n \times 100 \%
$$

Keterangan:

$\begin{array}{ll}\mathrm{P} & : \text { Persentase } \\ \mathrm{F} & \text { : Frekuensi } \\ \mathrm{n} & \text { : Sampel }\end{array}$

\section{PEMBAHASAN}

Hasil dari perhitungan menunjukkan bahwa hubungan antara dukungan, kertlibatan, kepercayaan, keyakinan dan kredibilitas, keterbukaan dan tingkat pencapaian tujuan dengan iklim komunikasi RRI Palangka Raya sebagai Lembaga Penyiaran Publik.

\section{Dukungan}

Untuk membuat iklim komunikasi di dalam LPP RRI Palangka Raya terasa menyenangkan bagi seluruh anggota organisasi maka diperlukan dukungan dari karyawan atau anggota. Bagaimana karyawan memandang bahwa komunikasi dengan atasan itu penting untuk mendukung aktivitas-aktivitas pelaksanaan program guna pencapaian tujuan organisasi. Dukungan karyawan memandang hubungan komunikasi dengan atasan dapat membangun dan meningkatkan kesadaran diri tentang "makna dan kepentingan perannya".

Berdasarkan hasil rata-rata sebesar 4,0 item dari 90 orang responden dapat diketahui bahwa responden secara umum setuju dengan pernyataan interaksi sesama karyawan di RRI Palangka Raya saling mendukung. Dalam bekerja, lingkungan kerja berpengaruh langsung terhadap sikap kerja dan menentukan prestasi kerja karyawan. Lingkungan kerja yang menyenangkan membuat sikap karyawan positif dan memberi dorongan untuk bekerja lebih tekun dan lebih baik. Sebaliknya, jika situasi lingkungan tidak menyengangkan mereka cenderung meninggalkan lingkungan tersebut.

Sebagaimana diungkap Ghiselli dan Brown (dalam Tjalla, 1989) bahwa lingkungan kerja berpengaruh terhadap kuantitas dan kualitas hasil kerja karyawan. Steers (1980) menyatakan bahwa pengaruh lingkungan dapat dilihat dari dua sisi, yaitu lingkungan luar dan lingkungan dalam. Lingkungan luar umumnya menggambarkan kekuatan yang berada di luar organisasi, sedangkan lingkungan dalam merujuk pada faktor-faktor di dalam organisasi yang menciptakan milieu kultural dan sosial tempat berlangsungnya kegiatan. Lingkungan dalam ini biasanya disebut dengan istilah iklim organisasi.

Menyadari betapa iklim organisasi memiliki kontribusi yang cukup signifikan terhadap setiap individu di organisasi LPP RRI Palangka Raya, yang pada ujungujungnya akan pula berpengaruh terhadap kualitas kerja, maka dengan sendirinya perlu pemahaman yang baik tentang iklim organisasi.

Berdasarkan hasil rata-rata item sebesar 4.17 dari 90 orang responden dapat diketahui bahwa responden secara umum setuju dengan pernyataan hubungan atasan dan bawahan cukup terbuka. Komunikasi ke bawah menunjukan arus pesan yang mengalir dari para atasan atau para pemimpin kepada bawahannya. Menurut Lewis (1987) komunikasi ke bawah adalah untuk menyampaikan tujuan, untuk merubah sikap, membentuk pendapat, mengurangi ketakutan dan kecurigaan yang timbul karena salah informasi, mencegah kesalahpahaman karena kurang informasi dan mempersiapkan 
anggota organisasi untuk menyesuaikan diri dengan perubahan.(Arni,) Kecuali untuk keperluan informasi rahasia, anggota organisasi harus relatif mudah memperoleh informasi yang berhubungan langsung dengan tugas mereka saat itu, yang mempengaruhi kemampuan mereka untuk mengkoordinasikan pekerjaan mereka dengan orang-orang atau bagian-bagian lainnya, dan yang berhubungan luas dengan perusahaan,organisasinya, para pemimpin dan rencana-rencana.

Berdasarkan hasil rata-rata item sebesar 4.4 dari 90 orang responden dapat diketahui bahwa responden secara umum setuju dengan pernyataan informasi menyebar ke seluruh karyawan di RRI Palangka Raya dengan mudah. karyawan/anggota memahami dengan baik mengapa dia harus meningkatkan kinerjanya. Dengan adanya penyebaran informasi komunikasi yang merata keseluruh karyawan, sehingga karyawan dan anggota merasakan mudah dan pentingnya tujuan tersebut dan harus meningkatkan kinerjanya untuk meningkatkan produktivitas dari organisasi. Berdasarkan hasil rata-rata item sebesar 4.12 dari 90 orang responden dapat diketahui bahwa responden secara umum setuju dengan pernyataan kerjasama seluruh karyawan di RRI Palangka Raya dan atasan dapat mempengaruhi pelayanan pada publik.

Pada masa sekarang ini organisasi banyak mendapat sorotan publik terutama dalam hal pelayanan. Masyarakat semakin kritis dan menginginkan pelayanan yang maksimal dari organisasi. Mereka menuntut pelayanan yang efektif dalam berbagai hal. Tidak hanya di pusat pemerintahan, di semua tingkat mendapatkan tuntutan yang sama dari publik yaitu pelayanan yang efektif. Ada banyak faktor yang bisa mempengaruhi efektivitas pelayanan suatu organisasi, diantaranya disiplin kerja dan iklim kerja karyawan LPP RRI Palangka Raya.

Berdasarkan hasil rata-rata item sebesar 4.35 dari 90 orang responden dapat diketahui bahwa responden secara umum setuju dengan pernyataan setiap karyawan di RRI Palangka Raya terdorong untuk memahami tujuan organisasi Komunikasi merupakan suatu bidang yang sangat penting dalam organisasi. Komunikasi dalam organisasi adalah suatu proses penyampaian informasi, ide-ide diantara para anggota organisasi secara timbal balik dalam rangka mencapai tujuan yang telah ditetapkan.

Berdasarkan hasil rata-rata item sebesar 3.89 dari 90 orang responden dapat diketahui bahwa responden secara umum setuju dengan pernyataan gaya kepemimpinan atasan dapat mendorong keberhasilan organisasi RRI Palangka Raya. LPPR RRI Palangka Raya menyadari pentingnya kepemimpinan dalam mengoperasikan suatu organisasi, namun gaya kepemimpinan yang dilaksanakan dapat mempengaruhi iklim komunikasi yang terjadi di dalam organisasi tersebut. Cara anggota organisasi bereaksi terhadap segenap aspek organisasi menciptakan sebuah iklim komunikasi. Iklim yang negatif benar-benar dapat merusak keputusan yang dibuat anggota organisasi mengenai bagaimana mereka akan bekerja dan berpartisipasi untuk organisasi.

\section{Keterlibatan}

Hasil rata-rata item sebesar 4.43 dari 90 orang responden dapat diketahui bahwa responden secara umum setuju dengan pernyataan setiap karyawan ikut memberi peran serta dalam meningkatkan peran RRI sebagai LPP. Hasil rata-rata item sebesar 4.01 dari 90 orang responden dapat diketahui bahwa responden secara umum setuju dengan pernyataan setiap karyawan mengerti posisinya dalam pengambilan keputusan yang dilakukan atasan. Hasil rata-rata item sebesar 4.2 dari 90 orang responden dapat diketahui bahwa responden secara umum setuju dengan pernyataan berusaha bersama untuk mencapai prestasi RRI.

Hasil rata-rata item sebesar 4.33 dari 90 orang responden dapat diketahui bahwa responden secara umum setuju dengan pernyataan mengakui keterbatasan karyawan lain. Hasil rata-rata item sebesar 4.21 dari 90 
orang responden dapat diketahui bahwa responden secara umum setuju dengan pernyataan setiap karyawan menyadari perannya di RRI dalam pelayanan pada public. Hasil rata-rata item sebesar 4.02 dari 90 orang responden dapat diketahui bahwa responden secara umum setuju dengan pernyataan setiap karyawan saling menjaga nama baik RRI.

Untuk menunjukkan kepada anggota organisasi bahwa organisasi tersebut mempercayai mereka dan memberi mereka kebebasan dalam mengambil resiko, mendorong mereka dan memberi mereka tanggung jawab dalam mengerjakan tugastugas mereka dan menyediakan informasi yang terbuka dan cukup tentang organisasi, mendengarkan dengan penuh perhatian serta memperoleh informasi yang dapat dipercayai dan terus terang dari anggota organisasi; secara aktif memberi penyuluhan kepada praanggota organisasi sehingga mereka dapat melihat bahwa keterlibatan mereka penting bagi keputusan-keputusan dalam organisasi dan menaruh perhatian pada pekerjaan yang bermutu tinggi dan memberi tantangan.

Iklim komunikasi di LPP RRI Palangka Raya itu penting karena secara tidak langsung iklim komunikasi organisasi dapat mempengaruhi cara hidup karyawan di dalam sebuah organisasi kepada siapa karyawan berbicara, siapa saja yang disukai, bagaimana perasaan masing-masing orang, bagaimana kegiatan kerja berlangsung dan bagaimana perkembangan karyawan di dalam organisasi (Pace dan Faules, 2002).

Menurut Redding, yang dikutip oleh Pace dan Faules menyatakan bahwa "iklim komunikasi organisasi jauh lebih penting daripada keterampilan atau teknik-teknik komunikasi semata-mata dalam menciptakan suatu organisasi yang efektif“. (Pace dan Faules, 2002)

Dari sini dapat dilihat bahwa iklim komunikasi di LPP RRI Palangka Raya itu perlu untuk diperhatikan agar dapat menciptakan sebuah organisasi yang efektif. Di dalam buku komunikasi organisasi yang ditulis oleh Pace dan Faules menegaskan hal ini dengan mengemukakan bahwa iklim komunikasi tertentu memberi pedoman bagi keputusan dan perilaku individu. Keputusan-keputusan yang diambil oleh anggota organisasi untuk melaksanakan pekerjaan mereka secara efektif, untuk mengikatkan diri mereka dengan organisasi, untuk bersikap jujur dalam bekerja, untuk meraih kesempatan dalam organisasi secara bersemangat, untuk mendukung para rekan dan anggota organisasi lainnya, untuk melaksanakan tugas secara kreatif, dan untuk menawarkan gagasan-gagasan inovatif bagi penyempurnaan organisasi dan operasinya, semua ini dipengaruhi oleh iklim komunikasi. Iklim yang negatif dapat benar-benar merusak yang dibuat anggota organisasi mengenai bagaimana mereka akan bekerja dan berpartisipasi untuk organisasi. (Pace dan Faules, 2002)

Iklim komunikasi yang penuh rasa persaudaraan mendorong para anggota organisasi untuk berkomunikasi sercara terbuka, rileks, ramah dengan anggota yang lain. Sedangkan iklim komunikasi yang negatif menjadikan anggota tidak berani berkomunikasi secara terbuka dan penuh rasa persaudaraan. (Arni, 2004).

Jadi, faktor keterlibatan karyawan iklim komunikasi memainkan peranan sentral dalam mendorong anggota organisasi untuk mencurahkan usaha kepada pekerjaan mereka dalam organisasi. (Pace dan Faules, 2002). Dari sini dapat dikatakan bahwa iklim komunikasi organisasi memiliki pengaruh yang cukup penting bagi motivasi kerja dan masa kerja pegawai dalam organisasi. Iklim komunikasi yang positif cenderung meningkatkan dan mendukung komitmen pada organisasi dan iklim komunikasi yang kuat seringkali menghasilkan praktik-praktik pengelolaan dan pedoman organisasi yang lebih mendukung (Pace dan Faules, 2002). Hal ini didukung pula Soemirat, Ardianto dan Suminar bahwa iklim komunikasi organisasi yang positif tidak hanya menguntungkan 
organisasi namun juga penting bagi kehidupan manusia-manusia di dalam organisasi tersebut. (Ardianto dan Suminar)

Dari uraian di atas mengenai iklim komunikasi organisasi, kita dapat melihat pentingnya peran iklim komunikasi organisasi bagi kehidupan sebuah organisasi. Oleh karena itu iklim komunikasi organisasi merupakan hal penting yang tidak boleh diabaikan, tetapi harus diperhatikan oleh organisasi.

3. Kepercayaan, Keyakinan Dan Kredibilitas

Berdasarkan hasil perhitungan kuisioner dari 90 orang respondent di atas dapat diinterpretasikan bahwa sebagian besar responden setuju perlu adanya tingkat kepercayaan, keyakinan dan kredibilitas antar sesama karyawan LPP RRI Palangka Raya terhadap iklim komunikasi yang ada dikantor lpp rri Palangka Raya tersebut. Personel di semua tingkat harus berusaha keras untuk mengembangkan dan mempertahankan hubungan yang di dalamnya terdapat kepercayaan, keyakinan dan kredibilitas yang didukung oleh pernyataan dan tindakan. Para pemimpin hendaklah berusaha membentuk kepercayaan di antara pengirim dan penerima pesan. Kepercayaan ini akan mengarahkan kepada komunikasi yang terbuka yang akan mempermudah adanya persetujuan yang diperlukan antara bawaha dan atasan. menemukan bahwa makin tinggi kepercayaan cenderung motivasi kerja makin tinggi.

\section{Keterbukaan}

Berdasarkan hasil perhitungan kuisioner dari 90 orang respondent di atas dapat diinterpretasikan bahwa sebagian besar responden setuju perlu adanya tingkat keterbukaan antar sesama karyawan LPP RRI Palangka Raya terhadap iklim komunikasi yang ada dikantor lpp rri Palangka Raya tersebut. Adanya keterbukaan tidak terlepas dari perkembangan teknologi informasi dan komunikasi. Dengan perkembangan teknologi dan komunikasi sulit bahkan tidak mungkin untuk menepis dan mengendalikan setiap informasi yang masuk. Dengan demikian, era keterbukaan secara tidak langsung akan mengakibatkan mengecilnya ruang dan waktu. Negara dituntut untuk lebih aktif dalam rangka menyaring dan mengendalikan setiap informasi yang masuk.

Keterbukaan adalah keadaan yang memungkinkan ketersediaan informasi yang dapat diberikan dan didapat oleh masyarakat luas. Keterbukan merupakan kondisi yang memungkinkan partisipasi masyarakat dalam kehidupan bernegara. Di samping itu, keterbukaan juga akan mengakibatkan batasbatas teritorial suatu negara menjadi kabur. Kecanggihan teknologi dan informasi membuat batas-batas teritorial suatu negara menjadi tidak berarti. Seseorang akan dengan mudah memberikan dan menerima informasi sesuai dengan keinginannya. Pada akhirnya keterbukaan akan mengakibatkan hilangnya diferensiasi (perbedaan) sosial. Akan tetapi, keterbukaan akan mempengaruhi berbagai aspek kehidupan di suatu negara. Di lihat dari aspek sosial budaya, keterbukaan akan memberikan ruang gerak bagi masuknya budaya-budaya barat yang sama sekali berbeda dengan budaya masyarakat Indonesia. Dilihat dari aspek ideologi, keterbukaan akan memberikan ruang bagi tumbuh dan berkembangnya ideologiideologi dari luar yang tidak sesuai dengan kepribadian suatu bangsa Indonesia. Oleh sebab itu, munculnya era keterbukaan akan membawa dampak yang sangat buruk apabila kita tidak dapat mempersiapkan diri.

\section{Tingkat Pencapaian Tujuan}

Berdasarkan hasil perhitungan kuisioner dari 90 orang respondent di atas dapat diinterpretasikan bahwa sebagian besar responden setuju perlu adanya tingkat pencapaian tujuan antar sesama karyawan LPP RRI Palangka Raya terhadap iklim komunikasi yang ada dikantor LPP RRI Palangka Raya tersebut.

Organisasi adalah suatu system yang terdiri dari pola aktivitas kerjasama yang dilakukansecara teratur dan berulang-ulang 
oleh sekelompok orang untuk mencapai suatu tujuan (Indriyo Gitosudarmo, 1997). Dari sini dapat dikatakan atau ditunjukkan bahwa organisasi memiliki unsur-unsur.Unsurunsur tersebut adalah sebagai berikut:1). Sistem.Bahwa organisasi adalah kumpulan dari sub-sub system.2). Pola AktivitasBahwa didalamnya ada aktivitas-aktivitas yang dilakukan orang yang dilaksanakan secararelative teratur dan cenderung berulang.3). Sekelompok Orang.Organisasi adalah kumpulan orang-orang.4). Tujuan.Setiap organisasi didirikan adalah untuk mencapai suatu tujuan.

\section{KESIMPULAN}

Berdasarkan hasil analisis dan pembahasan, maka dapat ditarik simpulan untuk menjawab tujuan penelitian sebagai berikut:

Iklim komunikasi di RRI Palangka Raya dapat digambarkan sebagai suatu suasana yang bermakna bagi para karyawan dalam menjalankan tugasnya sebagai karyawan RRI setelah ada perubahan posisi sebagai lembaga penyiaran public (LPP). Ini menunjukkan bahwa setelah perubahan sebagai LPP, karyawan RRI Palangka Raya juga merasakan perubahan, tidak hanya melayani publik secara eksternal tapi juga secara internal antar karyawan. Sebagai karyawan RRI, mereka memiliki keterikatan sesuai dimensi iklim komunikasi organisasi untuk saling mendukung dalam pencapaian tujuan pelayanan public, keterlibatan dalam berbagai peran dan tugas RRI dalam menjalankan fungsi social media massa, di samping factor saling percaya, diiringi keyakinan dan kredibilitas hubungan serta keterbukaan dalam organisasi, yang memberi makna pada iklim komunikadi di RRI Palangka Raya.

\section{SARAN}

Berdasarkan kesimpulan di atas, maka dapat disarankan kepada pemerintah Kota Palangka Raya tentang pelaksanaan Peraturan Pemerintah Nomor 53 tahun 2010 tentang
Disiplin PNS agar dapat dilaksanakan secara efektif adalah :

1. Dalam rangka menigkatkan kinerja dan disiplin pegawai, maka BKPP Kota Palangka Raya harus melakukan sosialisasi kembali Peraturan Pemerintah Nomor 53 tahun 2010 tentang Disiplin PNS ke seluruh Dinas/Badan/Kantor/Unit kerja di lingkungan pemerintah Kota Palangka Raya terjadwal dengan baik.

2. Perlu adanya pembinaan pegawai secara berkala di lakukan oleh BKPP ke setiap Dinas/Badan/Kantor/Unit kerja di lingkungan pemerintah Kota Palangka Raya.

3. Perlu adanya mutasi pegawai yang memang memiliki kualitas dan kemampuan di bidang hukum khususnya untuk ditempatkan di BKPP Kota Palangka Raya.

\section{REFERENSI}

Abdullah, Rozali 1986, Hukum Kepegawaian Jakarta. Jakarta, CV. Rajawali.

Arni Muhammad, 1989, Komunikasi Organisasi, Bumi Aksara, Jakarta.

Assegaff Dja'far h. 1991. Jurnalisme Masa Kini Pengantar ke Praktek Kewartawanan. Jakarta. Ghalia indonesia

Bungin, Burhan. 2005. Pornomedia, Sosiologi Media, Konstruksi Sosial Teknologi Telematika di Media Massa. Jakarta: Prenada Media

Daldiyono. 2002. How to Be A Real and Succesfull Student. Jakarta. PT Gramedia Pustaka Utama.

Dedy Mulyana, 2008, Metode Penelitian Komunikasi, PT. Remaja Rosdakarya, Bandung.

2011, Ilmu Komunikasi Suatu Pengantar, PT. Remaja Rosdakarya, Bandung.

-_-_-_-_ 2011, Komunikasi Lintas Budaya, PT. Remaja Rosdakarya, Bandung.

Ghozali Imam. 2009. Aplikasi Analisis Multivariate dengan Program SPSS, Semarang. Badan Penerbit Universitas Diponegoro.

Kriyantono, Rachmat. 2006. Teknis Praktis Riset Komunikasi. Jakarta. Kencana Prenada Media Group. 
Michael C. Keith, 2000, Stasiun Radio Teknologi, Internews Indonesia, Jakarta.

Mufid Muhammad. 2005. Komunikasi dan Regulasi Penyiaran. Jakarta. Prenada Media.

Mulyana Deddy, Solatun. 2008. Metode Penelitian Komunikasi. Bandung. PT Rosdakarya

Mulyana Deddy. 2009. Ilmu Komunikasi Suatu Pengantar. Bandung. PT Rosdakarya.

Onong Uchjana Effendy, 1992, Dinamika Komunikasi, PT. Remaja Rosdakarya, Jakarta.

Nasution Zulkarimen. 2004. Komunikasi Pembangunan Pengenalan Teori dan Penerapannya. Jakarta. Rajawali Pers

Rakhmat Jalaludin. 2007. Psikologi Komunikasi. Bandung. PT Remaja Rosda Karya

Rosady Ruslan. 1998. Manajemen Public Relation \& Komunikasi. Jakarta. Rajawali Pers.

Rosmawaty, HP. 2010, Mengenal Ilmu Komunikasi. Widya Padjajaran, Jakarta.

Shoemaker, Pamela J and Stephen D. Reese. 1991. Message. New York: Longman Publishing Group.

Siregar, Ashadi. 1998. Bagaimana Meliput dan Menulis Berita untuk Media Massa. Jogyakarta. Penerbit Kanisius

Tony Greener. 2002. Kiat Sukses Public Relations dan Pembentukan Citranya. Jakarta. Bumi Aksara.

Walizer, Michael H. and Paul L. Weinir. 1993. Metode dan Analisis Penelitian: Mencari Hubungan. Jilid 1. Terjemahan Arif Sadiman dan Said Hutagaol. Surabaya: Erlangga

Yusup Pawit M 2009. Ilmu Informasi, Komunikasi dan Kepustakaan. Jakarta. Bumi Aksara. 